\title{
Effects of mercury on antioxidant mechanisms in the marine phanerogam Posidonia oceanica
}

\author{
L. Ferrat ${ }^{1}$, M. Roméo ${ }^{2, *}$, M. Gnassia-Barelli ${ }^{2}$, C. Pergent-Martini ${ }^{1}$ \\ ${ }^{1}$ EqEL, University of Corsica, BP 52, 20250 Corte, France \\ ${ }^{2}$ Réponse des Organsismes aux Stress Environnementaux (ROSE), University of Nice Sophia Antipolis, UMR INRA UNSA 1112, Parc Valrose,
} BP 71, 06108 Nice, France

\begin{abstract}
Biochemical markers of oxidative stress such as catalase activity, glutathione S-transferase (GST) activity and levels of lipid peroxidation evaluated in terms of thiobarbituric acid reactive substances (TBARS) were measured in the sheaths of the marine phanerogam Posidonia oceanica (L.) Delile experimentally exposed to $0.01,0.1$ and $1 \mathrm{\mu g} \mathrm{Hg} \mathrm{l}^{-1}$ for $48 \mathrm{~h}$. Up to a threshold concentration of $0.1 \mu \mathrm{g} \mathrm{Hg} \mathrm{l^{-1 }}$, an increase in catalase and GST activities and TBARS levels was observed, indicating that the antioxidant mechanisms were overtaxed and could not prevent membrane lipid peroxidation. Paradoxically, at $1 \mu \mathrm{g} \mathrm{Hg} \mathrm{l}^{-1}$, the damage seemed to decrease, as the lipid peroxidation levels of exposed sheaths were lower than those of controls and as catalase and GST activities were not different from those of controls. A possible rapid induction of phytochelatins detoxifying mercury could occur at this high level of mercury.
\end{abstract}

KEY WORDS: Posidonia oceanica · Mercury · Glutathione S-transferase $\cdot$ Catalase $\cdot$ Lipid peroxidation $\cdot$ Oxidative stress

Resale or republication not permitted without written consent of the publisher

The use of bioindicators allows a rapid and reliable monitoring of environmental conditions over time. Indeed, in the light of their worldwide distribution, marine phanerogams would appear to be potentially valuable bioindicators (Brix et al. 1983). Studies on Posidonia oceanica (L.) Delile have confirmed this, revealing correlations between the mercury levels accumulated in the plant tissue and the concentrations of this metal in the water column (Pergent-Martini 1998). Mercury is one of the most abundant marine pollutants and, within the Mediterranean, elevated mercury levels have been reported in certain regions, especially in sediments (attaining up to $0.50 \mu \mathrm{g} \mathrm{g}^{-1}$ dry wt, Maserti \& Ferrara 1991). These observations, however, only provide an indication of past environmental

${ }^{*}$ Corresponding author. E-mail: romeo@unice.fr pollution, which limits the value of these results within the framework of an 'instantaneous' monitoring of the environment. It would thus appear of interest to seek more early warning symptoms of pollutant action through biomarkers, which are usually defined as molecular, biochemical and cellular changes brought on by chemical pollutants and which are measurable in biological mediums such cells, tissues and cellular fluids (McCarthy \& Shugart 1990).

Among the molecules found in the different metabolic pathways in animals and plants, those involved in oxidative processes show a good potential as biomarkers. The antioxidant molecules superoxide dismutase, catalase (EC 1.11.1.6), peroxidases, Vitamins $\mathrm{C}$ and $\mathrm{E}$ and glutathione have been found in different plants and are known to be induced by the production of reactive oxygen species (ROS) (Vangronsveld et al. 1997). Experimental exposures to organic contaminants (Pflugmacher et al. 2000) such as nitrobenzene derivatives and pesticide xenobiotics such as atrazine and heavy metals (Vangronsveld et al. 1997) have led to increased catalase and glutathione peroxidase and glutathione S-transferase (GST: EC 2.5.1.18) activities in plants. Moreover, the peroxidation of membrane lipids may result from the effects of heavy metals and herbicides (Vangronsveld et al. 1997).

The purpose of this study was to determine whether mercury contamination induces an oxidative stress in Posidonia oceanica. Several biochemical parameters, considered to be biomarkers of oxidative stress, were measured in the sheaths of the plant exposed to this metal. The chosen biomarkers were levels of thiobarbituric acid reactive substances (TBARS), which indicate if lipid peroxidation takes place; the activity of catalase, which is an anti-oxidant enzyme; and the activity of glutathione S-transferase, which can replace glutathione peroxidase in some redox cycles. 
Materials and methods. Collection: Shoots of Posidonia oceanica (L.) Delile were collected by SCUBA diving at $10 \mathrm{~m}$ depth in the Lérins Islands (Bay of Cannes, France). The shoots were dissected according to the protocol of Giraud (1979).

Mercury contamination: Experiments were carried out only on the non-chlorophyllian basal parts (sheaths) of the adult leaves, as chlorophyll could interfere with measurements (Hamoutène et al. 1996): 15 entire shoots (5 replicates for each biochemical analysis) were incubated for $48 \mathrm{~h}$ in aquaria filled with natural aerated seawater containing $0,0.01,0.1$ and $1 \mu \mathrm{g} \mathrm{l}^{-1} \mathrm{Hg}$ in the form of mercury chloride (temperature $=20 \pm 1^{\circ} \mathrm{C}$, salinity $=37.5 \%$, $\mathrm{pH}=8$, light:dark cycle $=10: 14 \mathrm{~h}$ ).
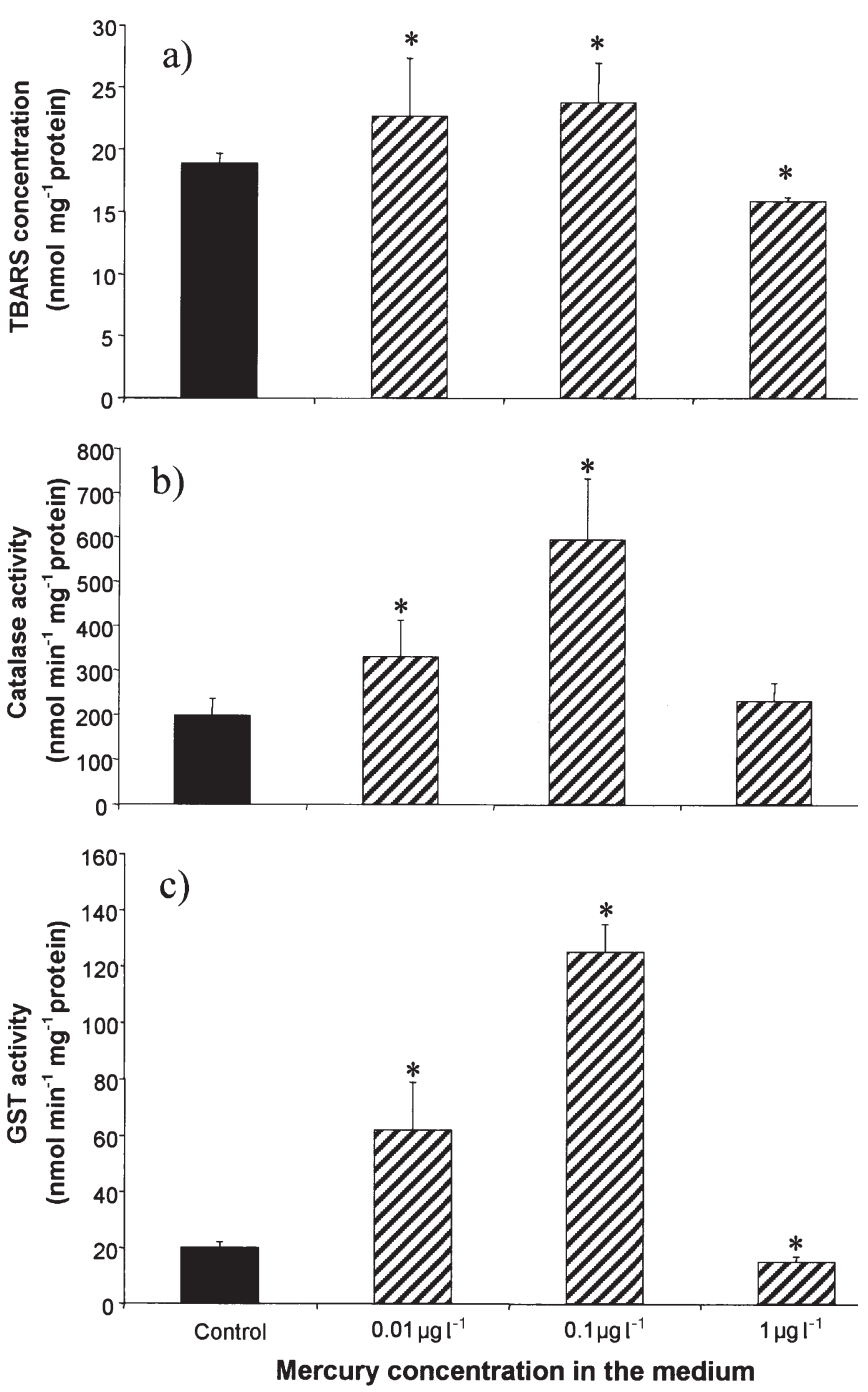

Fig. 1. Posidonia oceanica. Measurement of anti-oxidant defense in sheaths treated for $48 \mathrm{~h}$ with increasing concentrations of $\mathrm{Hg}(\mathrm{n}=5$ at each concentration). *Significantly different from controls, p $<0.05$ (Kruskal-Wallis test). (a) Thiobarbituric acid reactive substances (TBARS) concentration; (b) catalase activity; (c) glutathione S-transferase (GST) activity
Biochemical measurements: Following mercury exposure, the tissues were homogenized in a $\mathrm{pH} 8.4$ buffer according to the method of Hamoutène et al. (1996) for lipid peroxidation and catalase measurements and following Ranvier et al. (2000) for GST measurements. Centrifugation at $9000 \times g$ was subsequently done for 20 min to remove cell debris, nuclei and mitochondria. The supernatant was utilized for the biochemical assays. The protein levels were also determined in the supernatant, with bovine serum albumin (BSA) as a standard (Bradford 1976). Lipid peroxidation was estimated by the level of TBARS according to the procedure of Buege \& Aust (1978). Catalase (EC 1.11.1.6) activity was measured according to the procedure of Clairbone (1985), by following the decrease of $\mathrm{H}_{2} \mathrm{O}_{2}$. GST (EC 2.5.1.18) activity was measured with the substrate 1-chloro-2,4-dinitrobenzene (CDNB) by following conjugation of the acceptor substrate with reduced glutathione as described in Habig et al. (1974).

Results. Lipid peroxidation: The level of TBARS (Fig. 1a) was significantly higher in sheaths exposed to 0.01 and $0.1 \mu g \mathrm{Hg} \mathrm{l}^{-1}$, than in controls (18.84 \pm $0.81 \mathrm{nmol} \mathrm{mg}^{-1}$ protein; Kruskal-Wallis test, $\mathrm{p}<0$.05). A significant decrease was noted in sheaths contami-

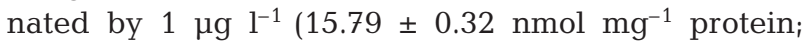
Kruskal-Wallis test, $\mathrm{p}<0.05)$, compared to the controls.

Catalase activity: Catalase activity (Fig. 1b) significantly increased (Kruskal-Wallis test, p < 0.05) in the sheaths contaminated by $0.01 \mu \mathrm{g} \mathrm{Hg} \mathrm{l}^{-1}$ (329 $\pm 83 \mathrm{nmol}$ $\mathrm{min}^{-1} \mathrm{mg}^{-1}$ protein, and $0.1 \mu \mathrm{g} \mathrm{l}^{-1}(594 \pm 138 \mathrm{nmol}$ $\mathrm{min}^{-1} \mathrm{mg}^{-1}$ protein), compared to the controls (198 \pm $37 \mathrm{nmol} \mathrm{min}{ }^{-1} \mathrm{mg}^{-1}$ protein). There was no significant difference in the case of $1 \mathrm{\mu g} \mathrm{l}^{-1}$ contamination.

GST activity: GST activity (Fig. 1c) increased significantly compared to the controls $\left(20 \pm 2 \mathrm{nmol} \mathrm{min}^{-1}\right.$ $\mathrm{mg}^{-1}$ protein) for $0.01 \mu \mathrm{g} \mathrm{Hg} \mathrm{l}^{-1}$ and $0.1 \mu \mathrm{g} \mathrm{l}^{-1}$ (62 \pm 17

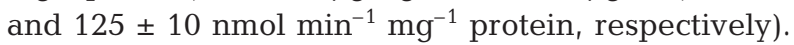
At the highest concentration $\left(1 \mu \mathrm{g} \mathrm{l}^{-1}\right)$, a significant

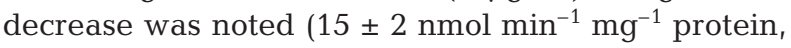
$\mathrm{p}<0.05)$ compared to the controls.

Discussion. Specimens of the marine phanerogam Posidonia oceanica were collected near the Lérins Islands (Bay of Cannes), where mercury concentrations in the surrounding waters ranged from 5 to $10 \mathrm{ng} \mathrm{l}^{-1}$ (Roméo 1985) and where concentrations in the plant reached 63 and $77 \mathrm{ng} \mathrm{g}^{-1}$ dry wt in the blades and sheaths, respectively (Ferrat 2001). Mercury uptake in $P$. oceanica occurs mainly through the root system (Maserti \& Ferrara 1991). Unfortunately, concentrations in the nearby sediments could not be measured. The chosen mercury concentrations that we added to the medium were relatively high in order to evaluate the effects of mercury concentrations in the medium in a short-term experiment. 
Lipid peroxidation, measured by the amount of TBARS, is one of the most important effects of oxidative stress. This biomarker, 'lipid peroxidation', is considered a biomarker of damage (Geffard 2001). Antioxidative mechanisms are involved in counteracting the oxidative stress in cells. In plants, the protective role of catalase was reported particularly in Lemna minor fronds in the presence of mercury by Subhadra et al. (1991). Marrs (1996) suggested that, in plants, a common effect of heavy metals, pathogen attack and/or wounding would be the generation of reactive oxygen species and that GSTs are induced in response to oxidative stress to protect cellular compounds from damage. Pascal \& Scalla (1999) hypothesized that GSTs can function in plants like glutathione peroxidases, which are major mechanisms of antioxidant defense. In a general manner, Vangronsveld et al. (1997) suggested that the induction of antioxidative enzymes is an indirect effect of metal toxicity.

Specimens of the marine phanerogam Posidonia oceanica exposed to 0.01 and $0.1 \mu \mathrm{g} \mathrm{Hg} \mathrm{l}^{-1}$ seemed to undergo an oxidative stress, since a significant increase in the TBARS levels was observed. The stress provoked by maintenance in aquaria must also be taken into account (Ferrat 2001), but we can presume that, at least during the experimental period of $48 \mathrm{~h}$, control and contaminated shoots were stressed in the same manner.

At the same concentrations (0.01 and $0.1 \mu \mathrm{g} \mathrm{Hg}^{-1}$ ), a significant increase in catalase and GST activities was also noted. Thus, the antioxidant mechanisms seemed to have been overwhelmed, since the catalase and GST activities were not strong enough to prevent membrane lipid peroxidation. Paradoxically, at $1 \mathrm{\mu g} \mathrm{Hg} \mathrm{l}^{-1}$ the damage seemed to be lower, as the lipid peroxidation levels of exposed sheaths were lower than those of controls and as catalase and GST activities were not different from those of controls. This result is in agreement with the results of Ranvier et al. (2000), who studied GST activity in the blades and sheaths of Posidonia oceanica contaminated with increasing concentrations of mercury $\left(0.01,0.1\right.$ and $1 \mu \mathrm{g} \mathrm{Hg} \mathrm{l}^{-1}$ ) for $48 \mathrm{~h}$, and with the results of Hamoutène et al. (1996), who studied anti-oxidant mechanisms in response to contamination by cadmium in $P$. oceanica sheaths. Our results, which showed low antioxidant activities and low lipid peroxidation levels in $P$. oceanica sheaths at the highest tested concentration $\left(1 \mu \mathrm{g} \mathrm{Hg} \mathrm{l}^{-1}\right)$, could have been due to involvement of other systems of protection against oxidative stress generated by mercury. Induction of phytochelatins in P. oceanica may occur. In fact, at high mercury concentrations, cellular glutathione may be depleted; a similar phenomenon was found in mussels treated with copper or mercury by Canesi et al. (1999). Glutathione levels in the tissues of $P$. oceanica col- lected from contaminated and pristine sites of the Mediterranean were lower in those plants exposed to high concentrations of mercury in the environment than in tissues of plants exposed to low amounts of this metal (Ferrat 2001). Glutathione, which is a precursor of phytochelatin synthesis (Gekeler et al. 1989), may be mobilized and consequently not be available as a substrate for GST activity. This may explain the decrease observed in GST activity. The induction of phytochelatins (PCs) may constitute an antioxidant defense at high metal levels and appears to be a mechanism of rapid protection that is activated before lipid peroxidation can be detected (Toppi et al. 1998) or before catalase can act as an antioxidant force. In a higher plant cell line, increased accumulation of PCs was detected as early as $5 \mathrm{~min}$ after exposure to cadmium (Robinson et al. 1988). In fact, plants produce 2 types of metal ligands: metallothionein proteins (MTs) and phytochelatin polypeptides (Cobbett 2000). In a recent study Giordani et al. (2000) investigated the presence of MTs in $P$. oceanica. The authors observed accumulation of MT transcripts after exposure to copper and cadmium, but not after exposure to mercury, suggesting that MTs are not key elements in mercury accumulation.

In conclusion, experimental exposure of Posidonia oceanica sheaths to relatively low concentrations of mercury chloride seems to induce oxidative stress in these tissues since a deleterious effect on the lipid membrane was observed and antioxidant defenses were mobilized. Catalase and GST respond quickly and constitute the first line of antioxidant defense. Biomarkers are useful for detecting chronic pollution in the environment rather than for measuring acute toxicity, and our experiments at low concentrations of mercury $\left(<1 \mu \mathrm{g}^{-1}\right)$ should be carried out over a longer period of time (a week or more) in order to mimic chronic pollution. Moreover, further research is needed to understand the role of glutathione, antioxidant enzymes and phytochelatin induction in the marine phanerogam $P$. oceanica exposed to mercury.

\section{LITERATURE CITED}

Bradford M (1976) A rapid and sensitive method for the quantification of microgram quantities of protein utilizing the principle of protein-dye binding. Analyt Biochem 72: 248-254

Brix H, Lyngby JE, Schierup HH (1983) Eelgrass (Zostera marina L.) as an indicator organism of trace metals in the Limfjord, Denmark. Mar Environ Res 8:165-181

Buege JA, Aust SD (1978) Microsomal lipid peroxidation. Methods Enzymol 52:302-310

Canesi L, Viarengo A, Leonzio C, Filippelli M, Gallo G (1999) Heavy metals and glutathione metabolism in mussel tissues. Aquat Toxicol 46:67-76

Clairbone A (1985) Catalase activity. In: Greenwald RA (ed) 
Handbook of methods for oxygen radical research. CRC Press, Boca Raton, FL, p 283-284

Cobbett CS (2000) Phytochelatins and their roles in heavy metal detoxification. Plant Physiol 123:825-832

Ferrat L (2001) Réactions de la phanérogame marine Posidonia oceanica en réponse à des stress environnementaux. Thèse, Université de Corse, Corte

Geffard A (2001) Réponses du biota à la contamination polymétallique d'un milieu estuarien, la Gironde, Fr: exposition, imprégnation, induction d'une protéine de détoxication, la métallothionéine, impact au niveau individuel et populationnel. Thèse, Université de Nantes

Gekeler W, Grill E, Winnacker EL, Zenk MH (1989) Survey of the plant kingdom for the ability to bind heavy metals through phytochelatins. Z Naturforsch Section C, Biosciences 44:361-369

Giordani T, Natali L, Maserti BE, Taddei S, Cavallini A (2000) Characterization and expression of DNA sequences encoding putative type-II metallothioneins in the seagrass Posidonia oceanica. Plant Physiol 123:1571-1581

Giraud G (1979) Sur une méthode de mesure et de comptage des structures foliaires de Posidonia oceanica (Linnaeus) Delile. Bull Mus Hist Nat Mars 39:33-39

Habig WH, Pabst MJ, Jakobi WB (1974) The first enzymatic step in mercapturic acid formation. J Biol Chem 249: 7130-7139

Hamoutène D, Roméo M, Gnassia M, Lafaurie M (1996) Cadmium effects on oxidative metabolism in a marine seagrass: Posidonia oceanica. Bull Environ Contam Toxicol 56:327-334

Marrs KA (1996) The functions and regulation of glutathione S-transferases in plants. Annu Rev Plant Physiol Plant Mol Biol 47:127-158

Maserti BE, Ferrara R (1991) Mercury in plants, soil and atmosphere near a chlor-alkali complex. Water Air Soil Pollut 56:15-20

Editorial responsibility: Silvano Bonotto, Torino, Italy
McCarthy JF, Shugart L (1990) Biomarkers of environmental contamination. Lewis Publishers, Boca Raton, FL

Pascal S, Scalla R (1999) Purification and characterization of a safener-induced glutathione S-transferase from wheat (Triticum aestivum). Physiol Plant 106:17-27

Pergent-Martini C (1998) Posidonia oceanica: a biological indicator of past and present mercury contamination in the Mediterranean Sea. Mar Environ Res 45:101-111

Pflugmacher S, Schröder P, Sanderman H Jr (2000) Taxonomic distribution of plant glutathione S-transferase acting on xenobiotics. Phytochemistry 54:267-273

Ranvier S, Gnassia-Barelli M, Pergent G, Capiomont A, Roméo M (2000) The effect of mercury on glutathione Stransferase in the marine phanerogam Posidonia oceanica. Bot Mar 43:161-168

Robinson NJ, Ratcliff RL, Anderson PJ, Delhaize E, Berger JM, Jackson PJ (1988) Biosynthesis of poly(gammaglutamylcysteinyl) glycines in cadmium-resistant Datura innoxia cells. Plant Sci 56:197-204

Roméo M (1985) Contribution à la connaissance des métaux traces $(\mathrm{Cd}, \mathrm{Cu}, \mathrm{Hg}, \mathrm{Pb}, \mathrm{Zn})$ dans l'écosystème marin au niveau du plancton. Approches analytiques et expérimentales. Thèse de Doctorat d'Etat, Université de Nice

Subhadra AV, Nanda AK, Behera PK, Panda BP (1991) Acceleration of catalase and peroxidase activities in Lemna minor L. and Allium cepa L. in response to low levels of aquatic mercury. Environ Pollut 69:169-179

Toppi LS, Lambardi M, Pecchioni N, Pazzagli L, Cappugi G, Durante M, Gabbrielli R (1998) Response to cadmium in carrot in vitro plants and cell suspension cultures. Plant Sci 137:119-129

Vangronsveld J, Mocquot B, Mench M, Clijsters H (1997) Biomarqueurs du stress oxydant chez les végétaux. In: Lagadic L, Caquet T, Amiard JC, Ramade F (eds) Biomarqueurs en ecotoxicologie, aspects fondamentaux. Masson, Paris, p 165-178

Submitted: February 18, 2002; Accepted: May 3, 2002 Proofs received from author(s): July 2, 2002 